\title{
POLA KETERBUKAAN DIRI ANTARA PERAWAT DAN LANJUT USIA DI PANTI SOSIAL
}

\author{
Ayu Yuhanis ${ }^{1}$, Richa Rahayu Mtd ${ }^{2}$, Hilman Ramayadi ${ }^{3}$ \\ ${ }^{1,3}$ Fakultas Ilmu Sosial dan Ilmu Politik Universitas Diponegoro \\ ${ }^{2}$ Fakultas Ilmu Sosial dan Ilmu Politik Universitas Sultan Ageng Tirtayasa
}

\begin{abstract}
ABSTRAK
Hubungan anak dengan orang tua semakin renggang. Kesibukan yang melanda kaum muda hampir menyita seluruh waktunya sehingga mereka hanya memiliki sedikit waktu untuk memikirkan orang tua. Kondisi seperti ini menyebabkan kurangnya komunikasi antara orang tua dengan anak, kurangnya perhatian dan pemberian perawatan terhadap orang tua sehingga orang tua merasa terasingkan dan lebih memilih tinggal di panti sosial. Oleh karena itu peneliti ingin menggambarkan proses komunikasi yang dilakukan oleh perawat dan lansia dan bagaimana pola keterbukaan diri antara perawat dan lansia di Panti Sosial Sasana Tresna Cipocok Jaya Serang. Penelitian ini menggunakan metode penelitian deskriptif kualitatif, data diperoleh melalui observasi, wawancara dan dokumentasi. Teori yang digunakan adalah teori penetrasi sosial, dimana proses ikatan yang menggerakkan suatu hubungan dari yang superficial menjadi lebih intim. Hasil penelitian menunjukkan bahwa semakin sering berinteraksi semakin kita mengetahui dan memahami karakter seseorang (perawat atau klien lansia), kedua belah pihak akan memberikan perhatian secara keseluruhan sehingga mulai terbiasa bersikap terbuka, santai, lebih akrab dan dapat memberikan solusi terhadap permasalahan yang dihadapi dan juga mampu menilai dan menduga perilaku lawan bicaranya. Pola komunikasi dalam proses keterbukaan diri antara perawat dan lansia di panti sosial sasana tresna werdha cipocok jaya serang adalah pola komunikasi sirkuler karena terjadinya umpan balik antara perawat dan lansia dalam melakukan interaksi.
\end{abstract}

Kata-kata Kunci: Pola keterbukaan diri, Perawat, Lanjut usia

\section{THE PATTERN OF SELF-DISCLOSURE BETWEEN NURSES AND THE ELDERLY IN SOCIAL HOME}

\begin{abstract}
Relationship of children with parents increasingly tenuous. The business that hit young people is almost time consuming because they have little time to think about their parents. Conditions like this cause the relationship between parents with children, attention and attention to parents so that parents feel alienated and prefer to live in a social home. Therefore the researchers want to explain the communication process undertaken by nurses and the elderly and how the pattern of self-disclosure between nurses and the elderly in Social Home Sasana Tresna Cipocok Jaya Serang. This research uses descriptive qualitative research method, data result through observation, interview and documentation. The theory used is the theory of social penetration, where the bonding process that moves a relationship from the superficial become more intimate. The results show that when we interact more, we know sooner and understand the character of a person (nurses or elderly), both sides will give attention as a whole so that getting used to be open, enjoy, more intimate, and can provide solutions to existing problems and also be able to
\end{abstract}


assess and reduce the behavior of the opponent. The pattern of self-disclosure between nurses and the elderly in social home sasana tresna werdha cipocok jaya serang is circular communication patterns because of the feedback between the nurses and the elderly in interaction.

Keywords: The Pattern of Self-Disclosure, Nurses, The Elderly

\section{PENDAHULUAN}

Penuaan adalah konsekuensi yang tidak dapat dihindari. Pada dasarnya lansia masih membutuhkan perhatian dan dukungan dari keluarganya sebagai tempat bergantung yang terdekat. Mereka ingin hidup bahagia dan tenang dihari tua serta masih ingin diakui keberadaannya. Pola keluarga yang semakin mengarah pada pola keluarga inti (nuclear family) mengakibatkan anak-anak secara tidak langsung kurang memperdulikan keberadaannya dan jalinan komunikasi antara orang tua dengan anak. Hal ini akan menyebabkan lansia merasa tersisih dan tidak lagi dibutuhkan peranannya sebagai anggota keluarga walaupun masih berada di lingkungan keluarga.

Zaman moderenisasi, hubungan anak dengan orang tua semakin renggang. Kesibukan yang melanda kaum muda hampir menyita seluruh waktunya sehingga mereka hanya memiliki sedikit waktu untuk memikirkan orang tua. Kondisi seperti ini menyebabkan kurangnya komunikasi antara orang tua dengan anak, kurangnya perhatian dan pemberian perawatan terhadap orang tua. Sebenarnya lansia tidak akan menimbulkan masalah yang berarti bagi keluarganya, apabila mereka masih mampu merawatnya. Namun jika keluarganya menjadi semakin sibuk dan tidak memiliki waktu yang cukup dan tenaga untuk merawatnya, maka salah satu jalan yang dipilih adalah menempatkan lansia di Panti jompo.

Panti jompo adalah tempat dimana berkumpulnya orang-orang lanjut usia yang secara sukarela ataupun diserahkan oleh pihak keluarga untuk diurus segala keperluannya, dimana tempat ini dikelola oleh pemerintah maupun pihak swasta. Sebagaimana tercantum dalam UU No.12 Tahun 1996 (Direktorat Jenderal, Departemen Hukum dan HAM), yaitu kewajiban Negara untuk menjaga dan memelihara setiap warganya. Akan tetapi, keputusan keluarga untuk menempatkan lansia di Panti jompo belum tentu diterima oleh lansia tersebut. Mereka mungkin saja merasa terbuang, tidak dibutuhkan lagi, terisolasi dan kehilangan orang-orang yang dicintai. Selain itu Panti jompo juga 
merupakan tempat yang relatif asing bagi lansia jika dibandingkan tinggal di rumah mereka sendiri bersama keluarga.

Lansia yang tinggal di Panti jompo akan mengalami suatu perubahan sosial dalam kehidupannya sehari-hari. Apabila lansia tidak segera mampu menyesuaikan diri dengan lingkungan baru yang ada di Panti jompo dan berusaha menjalin hubungan dengan orang lain yang seusianya, ketegangan jiwa atau stres akan muncul. Stres yang berkepanjangan dapat memperbesar penyakit fisik maupun mental dan tidak menutup kemungkinan lanjut usia akan mengalami keputusasaan.

Panti Sasana Tresna Werdha Cipocok Jaya Serang merupakan unit pelaksana teknis dinas sosial provinsi Banten yang menangani kesejahteraan sosial khususnya bagi lansia. Menyiapkan perawat untuk menangani keseharian lansia yang baru maupun yang sudah lama menetap agar para lansia dapat beradaptasi dengan lingkungan yang baru. Peran seorang perawat adalah menstabilkan suasana hati lansia dan mengurus serta merawat lansia karena merupakan salah satu tugas seorang perawat sebagai pengganti keluarga.

Seorang perawat ingin merawat lansia karena lansia mengalami kelemahan fisik dan mental, keterbatasan pengetahuan serta kurangnya kemampuan dan atau kemauan dalam melaksanakan aktivitas kehidupan sehari-hari secara mandiri, membantu memenuhi kebutuhan fisik lansia. Perawat yang ada di panti sosial sasana tresna werdha Cipocok Jaya Serang berlatar belakang dari lulusan pendidikan akademik perawat sehingga paham dan mengerti akan kebutuhan para lansia. Perawat yang bekerja di panti sosial tersebut berdasarkan atas kemauan mereka sendiri tanpa ada paksaan. Menurut seorang perawat yang bernama Ira Novita Sari, ia memilih bekerja di panti sosial karena ia ingin membuat orang-orang senang meskipun dengan melakukan hal-hal kecil apalagi membuat para lansia bahagia yang terlihat diraut wajahnya. Sehingga ia tidak merasa terbebani dalam melakukan pekerjaan di panti ini. Ini merupakan sebuah tantangan dalam menghadapi para lansia yang memiliki karakter yang condong ke kanak-kanakan. Ira mengatakan bahwa, "kelak nanti kita juga akan merasa posisi seperti mereka" (Wawancara dengan Ira Novita Sari, 18 Oktober 2017).

Melihat fenomena-fenomena saat ini, banyak sekali anak yang kurang memperhatikan dan memperdulikan 
orang tuanya sendiri.Fenomenafenomena anak menitipkan lansia di Panti Sosial Tresna Werdha Cipocok Jaya Serang.

Data lanjut usia yang tercatat di dinas sosial provinsi Banten mulai dari tahun 2012 sampai dengan 2017.

Tabel 1.1

Tabel Data Lanjut Usia

\begin{tabular}{|c|l|c|c|c|}
\hline \multirow{2}{*}{ No } & \multirow{2}{*}{ Tahun } & \multicolumn{2}{|c|}{ Kenis } & \multirow{2}{*}{ Kelamin } \\
\cline { 3 - 4 } & & Jumlah & L & \\
\cline { 3 - 4 } 1 & 2012 & 36 & 21 & 57 orang \\
\hline 2 & 2013 & 31 & 15 & 46 orang \\
\hline 3 & 2014 & 40 & 17 & 57 orang \\
\hline 4 & 2015 & 35 & 20 & 55 orang \\
\hline 5 & 2016 & 39 & 20 & 59 orang \\
\hline 6 & 2017 & 42 & 15 & 57 orang \\
\hline
\end{tabular}

Berdasarkan data tersebut, lansia dari tahun tahun 2012 sampai dengan tahun 2017 berkisar sekitar 57 sampai dengan 59 orang. Jadi, ini menjadi tugas bagi unit pelaksana teknis dinas sosial provinsi Banten dalam menangani kesejahteraan sosial dengan memberikan pelayanan bagi lansia yang bertujuan untuk meningkatkan kualitas hidup, kesejahteraan lanjut usia dan terpenuhinya kebutuhan dasar lanjut usia sehingga disinilah adanya peran seorang perawat kepada lanjut usia.
Interaksi perawat dengan lanjut usia dilakukan dengan cara berkomunikasi. Disamping lanjut usia juga dapat berinteraksi dengan dirinya sendiri, yang biasanya disebut dengan komunikasi intrapersonal, dan tentunya juga melakukan komunikasi dengan orang-orang sekitarnya untuk membuat dia bertahan hidup. Kehidupan manusia tidak akan terlepas dari komunikasi (Syam, 2011)

Pada hubungan komunikasi interpersonal, para komunikator membuat prediksi terhadap satu sama lain atas dasar data psikologis. Komunikasi interpersonal berperan dalam mentransfer peran/informasi dari sesorang kepada orang lain berupa ide, fakta, pemikiran serta perasaan. Oleh karena itu, komunikasi interpersonal adalah jembatan bagi setiap individu pada masyarakat dilingkungannya. Komunikasi antarpribadi selalu menimbulkan saling pengertian atau saling mempengaruhi antara seseorang dengan orang lain (Suranto, 2011).

Berdasarkan latar belakang yang jelas diatas, peneliti dapat merumuskan masalah untuk lebih fokos dalam menjawab tujuan penelitian. Rumusan masalahnya adalah bagaimana pola keterbukaan diri antara perawat dan lanjut usia di Panti Sosial Sasana Tresna 
Werdha Cipocok Jaya Serang. Tujuan diadakannya penelitian ini adalah untuk menggambarkan bagaimana pola keterbukaan diri pada tahap awal antara perawat dan lansia di Panti Sosial, menggambarkan bagaimana membangun proses keterbukaan diri antara perawat dan lansia di Panti Sosial dan menggambarkan bagaimana mempertahankan komunikasi interpersonal antara perawat dan lansia di Panti Sosial Sasana Tresna Werdha Cipocok Jaya Serang.

\section{METODE PENELITIAN}

Dalam penelitian ini peneliti menggunakan metode pendekatan kualitatif dimana peneliti hanya melakukan pemaparan situasi atau kondisi dan tidak mencari atau menjelaskan hubungan, tidak menguji hipotesis atau membuat prediksi. Sifat penelitian yang digunakan untuk mengidentifikasi permasalahan dalam kasus ini adalah sifat penelitian deskriptif dengan pendekatan kualitatif. Penelitian kualitatif dapat diartikan sebagai penelitian yang menghasilkan data deskriptif mengenai kata-kata lisan maupun tertulis dan tingkah laku yang diamati. Penelitian deskriptif dengan pendekatan kualitatif ini bertujuan untuk memaparkan dan mendeskriptifkan masalah-masalah yang ada secara terperinci dalam mengumpulkan informasi mengenai bagaimana membangun keterbukaan diri antara perawat dan lanjut usia di Panti Sosial.

Dalam penelitian kualitatif, peneliti menjadi instrumen. Oleh karena itu dalam penelitian kualitatif instrumennya adalah orang atau human instrument. Untuk dapat menjadi instrumen, peneliti harus memiliki bekal teori dan wawasan yang luas, sehingga mampu bertanya, menganalisis, memotret, dan mengkonstruksi obyek yang diteliti menjadi lebih jelas dan bermakna (Sugiyono, 2012).

Penentuan subjek penelitian dilakukan dengan teknik purposive sampling, teknik yang mencakup orangorang yang diseleksi atas dasar riset kriteria-kriteria tertentu yang dibuat periset berdasarkan tujuan riset (Krisyantono, 2009). Subjek penelitian yang diteliti dalam penelitian ini adalah Perawat dan Lansia di Panti Sosial Sasana Tresna Werdha Cipocok Jaya Serang. Peneliti memilih perawat dan lansia yang dijadikan subjek inti dalam penelitian ini dengan kriteria sebagai berikut: (a) perawat yang telah bekerja di Panti Sosial Sasana Tresna Werdha lebih dari lima tahun; (b) perawat perempuan dua orang dan laki-laki dua orang; (c) 
umur perawat antara 25 hingga 45 tahun; (d) umur lansia berkisar 65 hingga 68 tahun; (e) lansia yang tinggal di wisma tempat perawat bekerja.

Teknik pengumpulan data akan mempengaruhi kualitas dari data hasil penelitian. Kualitas pengumpulan data berkenaan dengan ketepatan cara-cara yang digunakan peneliti untuk mengumpulkan data. Pengumpulan data dapat dilakukan dalam berbagai setting, berbagai sumber, dan berbagai cara (Sugiyono, 2012). Untuk mendapatkan informasi atau data yang peneliti inginkan, maka dalam teknik pengumpulan data ini penelitian menggunakan teknik yang dilakukan, yakni observasi, wawancara dan dokumentasi.

Peneliti menggunakan teknik observasi berpartisipasi. Metode ini memungkinkan peneliti terjun langsung dan menjadi bagian yang diteliti bahkan hidup bersama-sama di tengah individu atau kelompok yang diobservasi dalam jangka waktu tertentu (Krisyantono, 2009). Observasi dilakukan di Panti Sosial Sasana Tresna Cipocok Jaya Serang.

Wawancara adalah percakapan dengan maksud tertentu. Pengumpulan data dalam penelitian ini menggunakan metode wawancara, sedangkan alat bantu yang akan digunakan adalah alat perekam berupa voice recorder, perekam gambar (handycam). (Moleong, 2013)

Pada proses wawancara ini pertanyaan yang diberikan tidak berstruktur, dan dalam suasana bebas yang santai maksudnya adalah menghilangkan kesan formal dengan menyesuaikan keadaan yang lebih kekeluargaan. Maksud mengadakan wawancara adalah untuk mengkonstruksi mengenai seseorang, kejadian, kegiatan, organisasi, perasaan, motivasi, tuntutan, kepedulian dan sebagainya. Dalam penelitian ini peneliti melakukan wawancara kepada penanggung jawab Panti Sosial, perawat dan lanjut usia (lansia) di Balai Perlindungan Sosial, Dinas Sosial Provinsi Banten tepatnya di Panti Sosial Sasana Tresna Werdha Cipocok Jaya Serang.

Dokumentasi menjadi salah satu teknik pengumpulan data yang penting. Disini peneliti melakukan dokumentasi saat studi lapangan di Panti Sosial Sasana Tresna Werdha Cipocok Jaya Serang.

Teknik analisis data yang digunakan dalam penelitian ini adalah analisis interaktif. Model ini ada 4 komponen analisis, yaitu: pengumpulan data, reduksi data, penyajian data dan 
penarikan kesimpulan. Menurut

(Moleong, Metodologi Penelitian

Kualitatif, 2004)

Pertama, pengumpulan data, yaitu mengumpulkan data di lokasi penelitian dengan melakukan observasi, wawancara dan dokumentasi dengan menentukan strategi pengumpulan data yang dipandang tepat dan untuk menentukan fokus serta pendalaman data pada proses pengumpulan data berikutnya. Kedua, reduksi data, yaitu sebagai proses seleksi, pemfokusan, pengabstrakan, transformasi data kasar yang ada dilapangan langsung dan diteruskan pada waktu pengumpulan data, dengan demikian reduksi data dimulai sejak peneliti memfokuskan wilayah penelitian.

Ketiga, penyajian data, yaitu rangkaian penyusunan informasi yang memungkinkan penelitian dilakukan. Penyajian data diperoleh berbagai jenis, jaringan kerja, keterkaitan kegiatan atau tabel. Keempat, penarikan kesimpulan, yaitu dalam pengumpulan data, peneliti harus mengerti dan tanggap terhadap sesuatu yang diteliti langsung di lapangan dengan menyusun pola-pola pengarahan dan sebab-akibat.

Metode keabsahan data diperlukan untuk menilai kesahihan (validitas) data dalam penelitian kualitatif. Triangulasi data merupakan teknik pemeriksaan keabsahan data dengan memanfaatkan sesuatu yang lain diluar data itu untuk keperluan pengecekan data atau sebagai perbandingan terhadap data itu.

Penelitian ini menggunakan dua macam triangulasi, pertama tiangulasi sumber data yang berupa observasi dan wawancara dengan narasumber secara langsung dan dokumen yang berisi catatan terkait dengan data yang diperlukan oleh peneliti. Lokasi penelitian dilakukan di Balai Perlindungan Sosial Dinas Sosial Provinsi Banten tepatnya di Panti Sosial Sasana Tresna Werdha Cipocok Jaya Serang.

\section{HASIL DAN PEMBAHASAN}

Peneliti akan mengkaji bagaimana pola komunikasi perawat dan lansia dalam komunikasi interpersonal yang mengkaitkan dengan teori komunikasi antarpribadi yaitu teori penetrasi sosial. Teori Penetrasi Sosial (Social Penetration Theory - SPT) dari Irwin Altman \& Dalmas Taylor (1973). SPT merupakan sebuah teori yang menggambarkan suatu pola pengembangan hubungan, yaitu sebuah proses yang Altman \& Taylor identifikasi sebagai penetrasi sosial. Dalam pola keterbukaan diri antara 
perawat dan lansia ini akan dibahas dari beberapa tahapan komunikasi yang ada didalamnya berdasarkan teori penetrasi sosial. Adapun identifikasi masalah yang akan dibahas pada hasil penelitian adalah sebagai berikut.

\section{Pola Keterbukaan Diri pada tahap awal antara Perawat dan Lansia}

Dalam penelitian ini yang dimaksud dengan pola keterbukaan diri antara perawat dan lansia di panti sosial sasana tresna werdha Cipocok Jaya Serang adalah jenis komunikasi dimana kita mengungkapkan informasi tentang diri kita sendiri yang biasanya kita sembunyikan dan menyampaikan informasi, keyakinan, perasaan, pengalaman dan masalah yang dirahasiakan kemudian diungkapkan kepada orang lain secara apa adanya, sehingga pihak lain memahami.

Tingkatan pengungkapan diri dimulai dari tahap dangkal dimana komunikasi biasanya terjadi antara dua orang yang bertemu dan diawali dengan sapaan atau basa-basi dan pertanyaan secara umum saja. Hal ini sesuai dengan pernyataan Okhe Afandi Maulana selaku perawat di panti sosial mengatakan bahwa:

"Dalam mengenali karakter klien lansia, perawat melakukan proses pendekatan. Sebelum melakukan pendekatan, kita sebagai perawat menganggap bahwa klien lansia itu orang tua bagi kita. Kemudian pendekatan dilakukan membutuhkan proses secara perlahan-lahan, karena tidak semua klien lansia memliki fisik dan psikologis yang sama. Waktu yang dibutuhkan dalam proses pendekatan dengan klien lansia paling cepat satu hari dan paling lama sekitar empat atau lima hari. Masing-masing klien lansia memiliki pendekatan yang berbeda dan metode pendekatannya juga berbeda."

Berdasarkan ungkapan di atas dapat menunjukkan bahwa waktu yang dibutuhkan dalam pola keterbukaan diri antara perawat dan lansia berbeda-beda, ada yang cuma satu hari bahkan ada yang sampai empat atau lima hari. Dalam berkomunikasi dengan klien lansia yang memiliki keterbatasan dalam penglihatan dan pendengaran atau pikun, dibutuhkan sentuhan berupa memberikan perhatian, memenuhi kebutuhannya, mengurus dan merawatnya, sedangkan lansia yang masih bisa mengurus dirinya sendiri lebih condong dijadikan partner atau teman dekat karena sifat klien lansia kembali lagi ke sifat anak-anak.

Dalam mengenali dan memahami karakter seorang klien lansia, bisa dikatakan sebagai tahap awal. Tahap awal yang bersifat klise, seperti perkenalan. Selain itu, yang dibicarakan 
juga hanya hal-hal yang umum saja, seperti menanyakan tentang nama, alamat, umur, bagaimana mendapatkan informasi tentang panti dan sebagainya. Sedangkan menurut Yani Heryani selaku kepala seksi pelayanan dan perawatan, mengatakan bahwa:

"Pengalaman saya selama bekerja di sini, mengenali karakter klien lansia membutuhkan waktu yang tidak dapat ditentukan. Setiap masing-masing klien lansia memiliki karakter yang berbeda-beda, karena setiap klien lansia tidak memiliki fisik dan psikologis yang sama. Ada waktu yang cepat dalam mengenali karakter lansia dan ada yang memang membutuhkan waktu yang lama. Paling cepat itu satu hari dan paling lama satu minggu atau lebih. Yang lebih intens berinteraksi dengan lansia itu adalah perawat. Akan tetapi, kita dari pihak balai perlindungan sosial di panti ini juga melakukan interaksi dan berkomunikasi seperti tegur sapa, memberikan senyuman, menanyakan hal-hal yang umum tentunya. Ada beberapa klien lansia yang baru masuk ke panti juga sulit untuk beradaptasi dengan yang lain, tetapi ada juga yang cepat dalam beradaptasi. Untuk itu butuh pendekatan secara emosional, sehingga klien lansia nyaman untuk tinggal di panti ini."

Berdasarkan ungkapan di atas dapat disimpulkan bahwa waktu yang dibutuhkan oleh Yani dalam pola keterbukaan diri dengan lansia sekitar satu minggu atau lebih. Dalam berinteraksi dan berkomunikasi dengan klien lansia butuh pendekatan secara emosional sehingga klien lansia merasakan kenyamanan tinggal di panti sosial.

\section{Membangun proses Keterbukaan Diri antara Perawat dan Lansia di Panti Sosial Sasana Tresna Werdha Cipocok Jaya Serang}

Berdasarkan temuan hasil penelitian di lapangan, membangun hubungan interpersonal diperlukan komunikasi yang baik dan efektif yang bertujuan untuk membentuk hubungan dan melakukan pertukaran informasi agar dapat membentuk saling pengertian dan terjalinnya hubungan yang harmonis dan baik. Dalam proses komunikasi individu sudah saling menanggapi agar terjadi pertukaran informasi dan adanya perluasan area publik. Individu yang mulai saling membuka diri namun masih terbatas pada taraf pikiran, saat berbicara individu tersebut masih berusaha keras menghindarkan diri dan menunjukkan kesan ramah dan mulai akrab. Hal ini dapat terlihat dari pengakuan Okhe Afandi Maulana selaku perawat yang mengatakan:

"Sejak klien lansia merasa nyaman, dengan sendirinya mereka cerita tanpa ditanya terlebih dahulu. Klien lansia bercerita tentang apa saja yang mereka rasakan. Biasanya cerita tentang teman sekamarnya, tetapi jarang sekali tentang keluarga mereka karena tidak 
semua klien lansia memiliki keluarga.".

Berdasarkan ungkapan di atas menunjukkan bahwa mulai adanya keterbukaan yang lebih mendalam dan adanya aspek-aspek dari kepribadian seorang individu mulai muncul dan sikap mulai akrab. Kemudian ada juga pernyataan, Narsiah seorang klien lansia juga mengatakan ia sering bercerita kepada perawat yang bernama Ira Novita Sari. Ia mengatakan bahwa:

“....nenek mah dekat sama siapa aja di panti. Tapi ada yang sering ngajakin nenek main ke rumahnya dan nginep di sana, namanya ibu Yani. Bu Yani sudah dianggap seperti anak sendiri. Kadang dibeliin baju buat lebaran sama bu Yani. Nenek juga dekat sama perawat di panti ini. Nenek sering cerita sama perawat Ira, Ia juga orang Padang sama kayak Icha. Banyak pokoknya yang diceritain, kadang cerita kalau nenek kangen keluarga dan pengen pulang. Tapi kalau nenek pulangnya sendirian, enggak dibolehin. Jadinya dianterin ke terminal Pandegalang, terus ditelepon keluarga nenek biar nenek dijemput ke terminal Pandeglang."

Narsiah mengungkapkan isi hatinya tentang ia rindu keluarganya kepada perawat yang bernama Ira Novita Sari, yakni ia rindu akan keluarganya, tetapi tidak diperbolehkan pulang sendiri ke rumahnya. Narsiah sudah menunjukkan sikap terbuka kepada Ira.
Sikap itu muncul saat Narsiah rindu sekali sama keluarganya sehingga Narsiah menceritakan isi hatinya kepada perawat Ira, sikap yang mulai akrab, sikap mulai terbuka dan santai.

Ketika melakukan komunikasi dalam proses membangun keterbukaan diri, tentunya ada saja hal yang menghambat dalam proses interaksi. Seperti pernyataan beberapa informan di atas bahwa hambatan komunikasi pada lansia secara fisik, biologi dan psikolohgis. Namun ada juga yang ditemukan beberapa hambatan komunikasi lainnya. Adapun hambatan komunikasi dalam komunikasi interpersonal antara perawat dan klien lansia di Panti Sosial Sasana Tresna Werdha Cipocok Jaya Serang adalah sebagai berikut:

\section{Gangguan}

a. Gangguan mekanik, ialah gangguan yang disebabkan saluran komunikasi atau kegaduhan yang bersifat fisik.

"Tentu saja ada, di panti ini tidak sedikit yang kita rawat klien lansianya, jadi setiap kita lagi bicara selalu ada hal yang mengganggu. Beberapa klien lansia tidak mau rahasianya diketahui sama yang lain. Ketika ada klien lansia yang serius cerita sama perawat, ada saja klien lansia yang suka mondar mandir keluar masuk kamar." 
b. Gangguan semantik, gangguan jenis ini bersangkutan dengan pesan komunikasi yang pengertiannya jadi rusak (salah pengertian).

"Terkadang ada klien lansia yang salah paham ketika kita menyuruh mereka seperti harus mandi biar bersih, cantik dan wangi, tetapi mereka menganggap mereka dimarahin dan tidak suka sama mereka."

2. Kepentingan

Kepentingan akan membuat seseorang selektif dalam menanggapi atau menghayati suatu pesan. Orang akan memperhatikan perangsang yang asa hubungannya dengan kepentigannya.

"Di panti sosial ini ada kegiatan rutin setiap minggunya, misalnya pengajian. Sebelum pengajian, biasanya perawat menyuruh para klien lansia untuk mandi terlebih dahulu. Tetapi ada saja klien lansia yang tidak memperdulikan dan ingin ikut, jika kita lihat dari kondisinya lagi tidak bersih dan bau. Yang namanya pengajian kan harus bersih dan suci, tapi kita dari perawat memaklumi dan menyuruh klien lansia untuk mandi."

3. Keterbatasan fisik

Hal ini berkaitan dengan berkurangnya fungsi fisik yang digunakan untuk berkomunikasi.

"Hambatan sih ada, yang namanya lansia kan ada keterbatasan fisik, seperti tidak bisa mendengar dengan jelas, tidak bisa melihat dengan jelas, pikun. Makanya perawat berbicara sedikit keras bagi klien lansia yang tidak bisa mendengar terlalu jelas."

\section{Gangguan psikologi}

Faktor psikologis sering menjadi hambatan dalam proses komunikasi. Hal ini umumnya disebabkan oleh komunikator sebelum melakukan proses komunikasi tidak melihat kondisi komunikannya, apabila komunikan lagi sedih, kecewa, marah dan kondisi psikologis lainnya.

"Selain hambatan pada keterbatasan fisik, juga ada gangguan pada psikologi klien lansia. Usia yang sudah tua itu kembali ke sifat anak kecil, terkadang suka tiba-tiba marah, sedih, kecewa dan sebagainya. Jadi, perawat harus sabar dan mengerti kondisi klien lansia”.

5. Prasangka

Prasangka merupakan salah satu rintangan atau hambatan berat bagi suatu kegiatan komunikasi.Oleh karena itu orang yang mempunyai prasangka belum apa-apa sudah bersikap curiga dan menentang komunikator yang hendak melancarkan komunikasi.

“Ada juga nih klien lansia yang suka salahpaham, misalnya perawat meminta membersihkan lingkungan wisma dan kamar mereka masingmasing. Tiba-tiba ada salah satu klien lansia yang merasa tersinggung, bisa dibilang meremehkan karena kamarnyanya kotor dan bau."

Dari uraian hambatan di atas, kita sudah mengetahui hambatan-hambatan komunikasi interpersonal dengan klien 
lansia, maka keterbukaan diri dapat mempengaruhi komunikasi yang dilakukan. Individu dapat lebih memahami apa yang dikatakan oleh orang lain apabila individu tersebut sudah mengenal baik orang lain tersebut, sehingga individu tersebut mendapatkan pemahaman secara utuh terhadap orang lain dan mungkin sebaliknya. Keterbukaan diri sangat diperlukan dalam membina suatu hubungan yang bermakna seperti sikap saling percaya, menghargai, dan jujur. Adanya keterbukaan akan membuat suatu hubungan lebih bermakna dan mendalam, sehingga membangun keterbukaan diri antara perawat dan lansia.

\section{Mempertahankan Komunikasi Interpersonal antara Perawat dan Lansia di Panti Sosial Sasana Tresna Werdha Cipocok Jaya Serang}

Kedekatan interpersonal merujuk pada sebuah ikatan hubungan dimana individu-individu yang terlibat bergerak dari komunikasi superfisial menuju ke komunikasi yang lebih intim. Keintiman yang bertahan lama membutuhkan ketidakberdayaan yang terjadi secara berkesinambungan tetapi juga bermutu dengan cara melakukan pengungkapan diri yang luas dan dalam.
Setiap individu memiliki emosi atau perasaan yang berbeda seperti individu yang menginginkan hubungan yang jujur, terbuka dan menyatakan perasaan secara mendalam. Individu yang memiliki keberanian untuk saling bersikap jujur dan terbuka berarti memiliki kesepakatan untuk saling mempercayai. Dengan begitu, komunikasi interpersonal dapat dipertahankan.

Sebagaimana ungkapan dari Ira Novita Sari selaku perawat di panti:

“...Iya, mereka langsung mendekat dan bercerita tentang apa saja. Biasanya mereka bercerita tentang teman sekamarnya. Kalau tentang keluarga, meraka sangat tertutup tetapi ada satu atau dua orang yang suka cerita tentang keluarganya. Klien lansia mulai mengungkapkan isi hatinya sejak mereka merasa nyaman tinggal disini atau nyaman dengan orang yang dekat dengan mereka..'

Ungkapan tersebut menjelaskan bahwa upaya pendekatan dalam keterbukaan diri dalam komunikasi interpersonal secara verbal pada kegiatan sehari-hari. Berbagai kegiatan seharihari yang dilakukan seperti bermain, membuat berbagai kerajinan, mengikuti pengajian, latihan qasidahan dan lainlain. Dengan melakukan berbagai kegiatan di panti sosial seseorang akan terbawa suasan santai seperti berada di 
lingkungan keluarga sendiri dan rumah sendiri. Begitu pula yang dirasakan oleh klien lansia yang tinggal di panti sosial, sehingga perasaan kaku dan tegang akan hilang.

Setelah data dianalisis, langkah selanjutnya adalah interpretasi data yaitu menghubungkan temuan hasil penelitian dengan teori dan konsep para ahli sehingga peneliti dapat mengembangkan teori dan menemukan makna baru dari hasil penelitian. Dalam hal ini peneliti membahas mengenai pola keterbukaan diri pada tahapan teori penetrasi sosial antara perawat dan lansia, membangun proses keterbukaan diri antara perawat dan lansia dan mempertahankan komunikasi interpersonal antara perawat dan lansia di Panti Sosial Sasana Tresna Werdha Cipocok Jaya Serang.

\section{Tahap awal dalam pola} keterbukaan diri pada teori penetrasi sosial, dalam penelitian ini teori yang digunakan dalam pola keterbukaan diri antara perawat dan lansia di panti sosial ialah teori penetrasi sosial. Teori penetrasi sosial mempunyai empat tahapan dalam perkembangan hubungan antar-individu. Tahap awal yang dilakukan perawat ialah tahap orientasi, dimana tahap saat komunikasi yang terjadi bersifat tidak pribadi (impersonal). Para individu yang terlibat hanya menyampaikan informasi yang bersifat sangat umum saja. Selama tahap ini, pertanyaan-pertanyaan yang dibuat biasanya hal-hal yang klise dan terjadinya respon seperti tersenyum manis dan bertindak sopan pada tahap orientasi.

Dari hasil temuan penelitian menunjukkan bahwa dari ketiga narasumber yaitu lansia yang tinggal di panti sosial tersebut ialah Suradi, Narsiah, dan Ratiah, masing-masing membutuhkan waktu yang berbeda-beda untuk melalui tahapan-tahapan penetrasi sosial. Beragam waktu yang mereka butuhkan untuk bisa terbuka kepada perawat di panti sosial. Pandangan perawat terhadap karakter lansia dalam berkomunikasi dan bagaimana cara berkomunikasi dengan lansia juga terdapat pada tahap orientasi. Dimana berkomunikasi dengan lansia harus berperan sebagai partner atau teman dekatnya dengan menanyakan hal-hal yang bersifat umum, mendengar cerita tentang apa saja sehingga tidak merusak interaksi meskipun dengan respon anggukan dan senyuman.

Tahap orientasi yang dilakukan hanya terdapat 4 point dari 8 point yang terdapat pada teori penetrasi sosial Atlman dan Taylor yang digunakan oleh informan, yang ditandai dengan 
informasi umum, pertanyaan yang superfisial (dangkal) dan bersifat umum dan berperilaku sesuai dengan hasil wawancara pada hasil penelitian.

Membangun keterbukaan diri, proses komunikasi individu sudah saling menanggapi agar terjadi pertukaran informasi dan adanya perluasan area publik. Individu yang mulai saling membuka diri namun masih terbatas pada taraf pikiran, saat berbicara individu tersebut masih berusaha keras menghindarkan diri dan menunjukkan kesan ramah dan mulai akrab.

Berdasarkan hasil penelitian yang sudah dipaparkan di atas, bahwa mulai adanya keterbukaan diri yang lebih mendalam, aspek-aspek kepribadian seseorang mulai muncul pada klien lansia Narsiah, Ratiah dan Suradi kepada perawat maupun teman dekat mereka masing-masing. Kemudian, mereka lebih memilih bercerita pada saat santai dan keakrabannya terlihat dari kedekatan diantara mereka seperti menceritakan hal-hal yang semiprivate kepada orang yang menurut mereka bisa dipercayai seperti perawat dan teman dekat.

Perawat di panti sosial melakukan proses komunikasi yang bertujuan untuk membangun keterbukaan telah menggunakan tahap ekspolatif pada teori penetrasi sosial menurut Atlman dan
Taylor. Keterbukaan diri sangat sangat diperlukan dalam membina suatu hubungan yang bermakna dan mendalam sehingga membangun proses keterbukaan diri antara perawat dan lansia.

Berdasarkan hasil wawancara dengan beberapa informan pada hasil penelitian di atas, menyebutkan bahwa hambatan komunikasi dalam berinteraksi dengan lansia adalah hambatan secara fisik, biologis dan psikologis. Namun peneliti mengamati dan merasakan masih ada hambatan lainnya dan ini terdapat pada faktor penghambat komunikasi antarpribadi. Proses-proses pertukaran itu berlangsung sistematis dan teratur, kali ini dari tingkat yang akrab ke tingkat yang tingkat akrab (Ganiem, 2012).

Begitu pula dalam membangun keterbukaan diri di sebuah panti sosial antara perawat dan lansia pasti mengalami berbagai hambatan atau masalah. Hambatan yang pertama ialah gangguan mekanik dan semantik, yang termasuk gangguan mekanik disini adalah ketika ada lansia yang ingin bercerita soal keluarganya kepada perawat. Kemudian gangguan semantik, seperti ketika seorang perawat menyuruh lansia mandi dengan suara yang sedikit 
keras, membuat lansia mengira bahwa perawat sedang marah.

Hambatan kedua ialah kepentingan, terjadi ketika perawat sedang mempunyai kepentingan yaitu menyuruh para lansia untuk mandisebelum kegiatan pengajian. Ketika sudah berkumpul di mushola, ada lansia yang belum mandi bahkan masih memakai baju yang sudah kena kencing dari kemarin dan belum diganti. Oleh karena itu, perawat harus bisa memahami dan memaklumi dan memberikan kesempatan untuk mandi terlebih dahulu.

Hambatan yang ketiga ialah keterbatasan fisik, hal ini berkaitan dengan berkurangnya fungsi fisik yang digunakan untuk berkomunikasi. Ini terjadi ketika perawat meminta tolong untuk membersihkan kamar mereka sendiri dengan suara yang lembut, ada beberapa lansia tidak dapat mendengar dengan jelas apa yang diucapkan oleh perawat dikarenakan alat indra beberapa lansia sudah mulai tidak berfungsi. Oleh karena itu, perawat berbicara dengan suara yang sedikit keras bagi beberapa lansia yang mempunyai keterbatasan dalam pendengaran.

Kemudian adanya hambatan psikologi yang timbul adanya perbedaan gagasan dan penilaian subyektif diantara orang yang terlibat dalam komunikasi. Gangguan psikologi ini terjadi dalam hal ketika perawat meminta lansia untuk keluar dari kamarnya dan beradaptasi dengan yang lain dengan suara yang lembut, tiba-tiba lansia itu marah karena ia tidak mau diatur. Dengan begitu, perawat harus lebih sabar dan mengerti dengan sikapnya yang terkadang suka baik dan suka tiba-tiba marah.

Hambatan yang terakhir ialah prasangka, ini terjadi ketika perawat sedang menasehati para lansia mengenai kebersihan lingkungan baik di kamar maupun di wisma, akan tetapi terkadang lansia yang salahpaham terhadap perawat. Mereka mengira bahwa perawat sedang mengucilkan mereka dan merasa diremehkan karena wismanya kotor dan bau.

Dengan mengetahui hambatanhambatan komunikasi interpersonal dengan lansia, maka keterbukaan diri dapat mempengaruhi proses komunikasi yang dilakukan. Individu dapat lebih memahami apa yang dikatakan oleh orang lain apabila individu tersebut sudah mengenal baik orang lain, sehingga individu tersebut mendapatkan pemahaman secara utuh terhadap orang lain dan mungkin sebaliknya.

Mempertahankan komunikasi interpersonal, kedekatan interpersonal 
merujuk pada sebuah ikatan hubungan dimana individu-individu yang terlibat bergerak dari komunikasi superfisial menuju ke komunikasi yang lebih intim. Keintiman yang bertahan lama membutuhkan ketidakberdayaan yang terjadi secara berkesinambungan tetapi juga bermutu dengan cara melakukan pengungkapan diri yang luas dan dalam.

Berdasarkan hasil penelitian di lapangan bahwa kedekatan hubungan interpersonal antara perawat dengan lansia di Panti Sosial Sasana Tresna Werdha Cipocok Jaya Serang bahwa seseorang telah merasa nyaman, mendapatkan timbal balik dari lawan bicaranya, terjalinnya persahabatan, lebih aktif, mau menceritakan masalah yang bersifat pribadi dan adanya hambatan. Hal ini bisa dilihat dari pembicaraan antara Ratiah, perawat dan teman dekatnya, disini Ratiah menceritakan masalahnya, perawat dan teman dekatnya juga memberikan solusi untuk Ratiah dalam menyelesaikan masalahnya itu.

Dari hasil penelitian tersebut, perawat dapat dikatakan melakukan tahap terakhir yaitu tahap pertukaran stabil. Kecenderungan perawat dalam melakukan komunikasi dengan lansia adalah mampu memahami apa yang dirasakan lansia dari raut wajahnya sehingga perawat melakukan berbagai pendekatan. Pada hal pengembangan hubungan dibutuhkan sebuah pendekatan begitu pula dalam pola keterbukaan diri antara perawat dan lansia di panti sosial. Pendekatan yang dilakukan perawat terhadap lansia yang memiliki sifat lebih condong seperti anak kecil berbeda dengan pendekatan dengan orang dewasa.

Hubungan interpersonal berkembang secara bertahap dan dapat diprediksi. Teoretikus penetrasi sosial percaya bahwa pembukaan diri adalah cara utama yang digunakan oleh sebuah hubungan ramah-tamah bergerak menuju hubungan yang intim. Meskipun pembukaan diri juga dapat menyebabkan satu orang atau lebih berada pada posisi yang rentan (Turner, 2008).

Selain itu dalam mempertahankan komunikasi antara perawat dan lansia di panti sosial, bisa juga melalui lima kualitas umum seperti yang disebutkan oleh Joseph A. DeVito yaitu keterbukaan, perilaku positif, perilaku suportif, empati, dan kesamaan. Itu ditemukan pada saat observasi di lapangan.

Berdasarkan hasil obeservasi, dalam komunikasi antarpribadi antara perawat dengan lansia perawat lah yang terlebih dahulu berperan menciptakan 
keterbukaan (openness) terhadap lansia dengan cara berkenalan, saling bercerita, membuka diri dan mendengarkan keluhan serta pendapat lansia. Dari hasil penelitian yang dilakukan oleh peneliti, peneliti mengetahui bahwa keterbukaan yang terjalin di antara perawat dengan klien lansia dilakukan dengan cara menciptakan suasana kekeluargaan seperti komunikasi yang dilakukan antara anak kepada orang tuanya sehingga membuat para lansia merasa nyaman berada di dekat perawat. Kualitas umum yang kedua yaitu perilaku yang positif. Penerapan perilaku positif yang dilakukan perawat kepada lansia dengan melayani lansia di panti sosial dengan baik

Kemudian yang ketiga adalah empati (empathy), perawat harus mampu merasakan apa yang sedang dirasakan oleh lansia karena emosi klien lansia yang sudah mulai tidak stabil membuat klien lansia menjadi lebih sensitif dan sering mengalami perubahan suasana hati. Kualitas umum yang keempat adalah perilaku suportif (suportiveness), perawat selalu memberikan nasihat dan semangat kepada para klien lansia untuk tetap kuat dan tegar dalam menjalani hidup.

Kualitas umum yang kelima adalah kesamaan (equality), maksudnya adalah komunikasi antarpribadi umumnya akan lebih efektif bila para pelakunya mempunyai nilai, sikap, perilaku dan pengalaman yang sama. Perawat berperan dalam menumbuhkan perasaan yang sama atau kesetaraan baik di antara perawat dengan klien lansia maupun antara lansia dengan lansia lainnya yang juga tinggal di panti. Kelima hal tersebut dijalankan sepenuhnya oleh para perawat di Panti Sosial Sasana Tresna Werdha Cipocok Jaya Serang ini dalam hal berkomunikasi dan membentuk hubungan dengan lansia yang tinggal di panti.

\section{SIMPULAN}

Berdasarkan hasil analisis yang telah dibahas sebelumnya, maka peneliti dapat mengambil beberapa kesimpulan, antara lain:

1. Pola komunikasi yang terjadi antara perawat dan lansia di Panti Sosial Sasana Tresna Werdha Cipocok Jaya Serang ialah pola komunikasi antarpribadi, dimana bertujuan untuk menggambarkan bagaimana pola keterbukaan diri antara perawat dan lansia dengan menggunakan teori penetrasi sosial Irwin Altman \& Dalmas Taylor (1973) melalui empat tahapan, yaitu tahap orientasi, tahap pertukaran eksploratif, tahap 
pertukaran afektif, dan tahap

pertukaran stabil. Jadi, pola

keterbukaan diri antara perawat dan

lansia adalah mulai dari tahap awal atau membuka diri sedikit demi sedikit bersifat impersonal yang membutuhkan waktu tertentu, semakin sering berinteraksi semakin kita mengetahui kepribadian lansia (superfisial menjadi intim), kedua belah pihak akan memberikan perhatian secara keseluruhan sehingga mulai terbiasa bersikap terbuka, lebih akrab dan terjalinnya persahabatan dan kedua belah pihak mampu memahami karakter dan menduga perilaku lawan bicaranya.

2. Upaya dalam membangun keterbukaan diri antara perawat dan lansia di Panti Sosial Sasana Tresna Werdha Cipocok Jaya Serang, antara lain:

a. Melayani, sebagaimana anak memberikan kasih sayang terhadap orang tua. Sehingga lansia merasa nyaman serta tidak merasa kaku.

b. Merawat dan memenuhi kebutuhan lansia, sebagaimana anak memberikan perhatian terhadap orang tua. Sehingga lansia merasa diperdulikan. c. Menumbuhkan kedekatan, berusaha menciptakan suasana seperti dirumah layaknya anak kepada orang tua.

d. Mendidik, dengan cara memberikan pemahaman dan pengertian atau nasehat yang baik.

Dalam mempertahankan komunikasi interpersonal antara perawat dan lansia di Panti Sosial Sasana Tresna Werdha Cipocok Jaya Serang, hal yang dilakukan ialah menciptakan suasana kekeluargaan seperti komunikasi yang dilakukan antara anak kepada orang tuanya seperti penerapan lima kualitas umum yang disebutkan oleh Joseph A. DeVito, yaitu keterbukaan, perilaku positif, perilaku suportif, empati dan kesamaan.

\section{DAFTAR PUSTAKA}

Aprilia, T. (2016). Pola Komunikasi Terapeutik Dokter terhadap Pasien Rawat Inap dalam Proses Penyembuhan. Studi Deskriptif Kualitatif Aktivitas Komunikasi Interpersonal Dokter dan Pasien di Rumah Sakit Krakatau Medika. .

Ganiem, M. B. (2012). Teori Komunikasi Antarprbadi. Jakarta: Kencana Prenada Media.

Iqbal, A. (2014). Pola Komunikasi Antarpribadi Guru Sekolah Khusus Negeri (SKhN) 01 Kota Serang dengan Murid Penderita Tunagrahita dalam Proses Belajar Mengajar di Kelas. . 
Krisyantono, R. (2009). Teknik Praktis Riset Komunikasi. Jakarta: Kencana.

Moleong, L. J. (2004). Metodologi Penelitian Kualitatif. Bandung: Reamaja Rosda Karya.

Moleong, L. J. (2013). Metodologi Penelitian Kualitatif. Bandung: Remaja Rosda Karya.

Putriana, D. (2016). Pola Komunikasi Pengasuh dengan Lanjut Usia di Pelayanan Sosial Lanjut Usia Tresna Werdha Natar, Lampung Selatan. .

Sugiyono. (2012). Memahami Penelitian Kualitatif. Bandung: Alfabeta.

Suranto, A. (2011). Komunikasi Interpersonal. Yogyakarta: Graha Ilmu.

Syam, N. W. (2011). Psikologi Sebagai Akar Ilmu Komunikasi. Bandung: Remaja Rosdakarya.

Turner, R. W. (2008). Pengantar Teori Komunikasi; Analisis dan Aplikasi Buku 1-3/E. Jakarta: Salemba Empat.

Undang-Undang Nomor 12 Tahun 2006

Undang-Undang Nomor 13 Tahun 1998

Undang-Undang RI Nomor 23 Tahun 1992 